\title{
Assessment of Bioclimatic comfort using different methods in the Chaldran Region's (in Iran)
}

\author{
Mohammad Yazdani \\ Ph.D. student of Climatology, Department of Climatology, Faculty of Plnning and \\ Environmental Sciences, Tabriz University, Tabriz, Iran yazdani@tabrizu.ac.ir
}

\begin{abstract}
Climate is one of the factors shaping the environment that directly affects human activities. The use of climatic elements in most plannings, including planning for tourism, is of great use. So that tourists are looking for leisure time in areas that have a favorable climate. Favorable climatic conditions attract tourists and lead to the development of tourism. In this research, the natural and historical features of Chaldran were first introduced. And the Chaldran climates were categorized in the climatic classification of the De Martonne and Emberger. Then, the bioclimatic comfort of Chaldran city were analyzed using tourism climate index(TCI) and Thermo- hygrometric index(THI) in order to plan tourism development according to appropriate tourism seasons. For this purpose, the 13year data of the Chaldran Synoptic Station between 2004 up to 2016 was used. The results of the TCI model indicate that April, May and July, respectively, with a final coefficient of 72, 77 and 72, are very good conditions, and the months of June, August, September and October, with a factor of 90, 82, 82 and 81, respectively, are excellent climatic conditions for tourists. The results of the THI model also showed that the month of May is cool and the months of June, July, August and September have favorable climate conditions for tourism. In total, the comfort of climate for tourism in the Chaldran region, with a 75 percent coverage of the year, shows a special ability and special talent for tourism development.
\end{abstract}

Keywords: Climate Classification, Bioclimatic Comfort, TCI model, THI model, Chaldran, Tourism

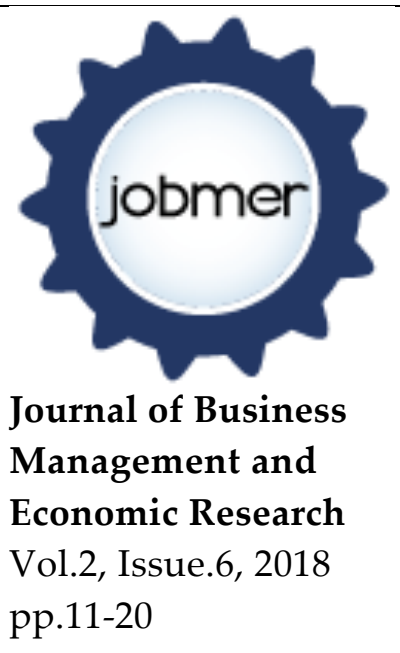

Doi: 10.29226/TR1001.2018.38 


\section{Introduction}

In general, tourism industry includes a flow of capital, human beings, culture, and interaction between them, which has different effects in geographic space. (Briedenhamm2004:7). Among these effects, we can mention the impact of tourism on economy and development. It forms a major part of the global economy and is considered to be the largest industry in the world(WTO1999:20). Climate and tourism as the main components of a dynamic system affect each other in different ways, and they interact with each other as a new discussion as the tourism Climatology(Lecha and Shachleford1997:15). The climate is very important from the point of view of tourism planning. Tourists tend to look for a favorable climate in which the person does not feel any climate dissatisfaction and this plays a significant role in making decisions for the destination of tourism(Matzarakis2001:39). Bio climatic researches are a foundation in urban planning, architecture and tourism development(Afzalinia2014:178). The bioclimatic investigates, made over time, have confirmed that the subjective perception which the human body feels regardless of the environmental conditions is the basis for the definition of the state of bioclimatic comfort or discomfort(Ionac 2007:128).Bioclimatic comfort conditions are usually associated with indicators that interfere with a set of meteorological, human, and environmental elements. These indicators provide climatic data in a way that reflects the response of people to climatic conditions and in a numerical classification, they range from the most appropriate to the inappropriate. These indicators make it easier to interpret the complex effects of atmospheric elements on human comfort And the possibility of comparing different places in terms of climate comfort. Climatic comfort indicators can examine the relationship between climate and tourism. The tourism climate index (TCI) and the Thermo- hygrometric index (THI) are two indicators of these indices. Each of these indicators, using a variety of climatic parameters, examines climatic comfort in a region and determine the appropriate time for tourism in an area. In general, this indicator states that, at a given time, the combination of different climatic elements is suitable for tourists, travelers or even residents of an area, or not? A wide range of studies have been carried out on the relationship between climatic and tourism factors and the assessment of climate comfort conditions. For example, Matzarakis (2004), (2007) and (2008), Hin (2009), Aloquardo (2004), Morabito (2004), Hartz (2006), Farajzadeh and Matzaralis (2009), Zolfaghari (2007), Yilmaz (2002) and Zengin (2009) has studied the role of climatic factors in the tourism industry and analyzed the climate comfort conditions of their studied areas.

\section{The study area}

Chaldran is one of the cities of West Azarbaijan province located in the northwestern part of Iran at 44 degrees 41 minutes east and 38 degrees 55 minutes north latitude. Chaldran can be one of the destinations for tourism due to cold weather in winter and cool in the heat season. This city with an area of 5,000 square kilometers is bounded to the north by the city of Maku and from the west to the border between Iran and Turkey and from the south to Khoy. Chaldran is located on a fertile plain next to the border elevations, and is also known as the Chaldran plain. January with an average temperature of -4.5 and a month of August with an average temperature of $22.2^{\circ} \mathrm{C}$, respectively, are the coldest and hottest months of the year. Chaldran climates were categorized in the De Martonne and Emberger climate classification, Mediterranean, $(\mathrm{I}=22.6)$ and semi-humid $(\mathrm{Q}=30.1)$, respectively. The center of this city is Siah Cheshmeh (Qara Eyni) and its height is 1936 meters above sea level, that is one of the highest cities in Iran.The city of Chaldran has a historical significance due to the Safavid Turks' wars with the Ottoman Turks. The Qara church and the tomb of the minister of Shah Isma'il are located in this city. In the Qara church, one of the apostles of Holiness Jesus Christ is buried. In 
Figure 1, the location of the study area is shown in the map of Iran and within the province of West Azarbaijan province.

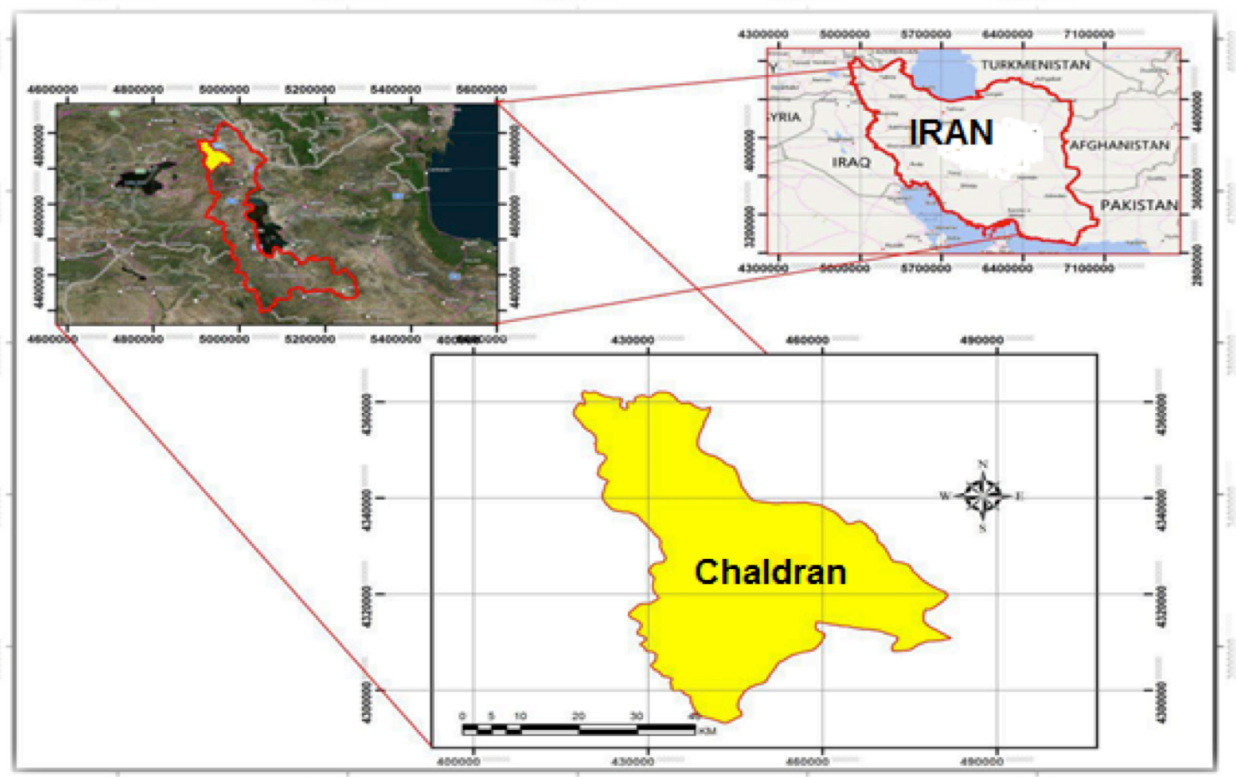

Fig1: The study area

\section{Methods}

The favorable climate along with other natural conditions is considered one of the bases of tourism development. Therefore, determining the type of climate in the study area is one of the goals of this study. For this purpose, meteorological data of the city's synoptic station was used in a 13-year statistical period from 2004 to 2016. For this purpose, the climate of the area was calculated in the climatic classification of De Martonne and Emberger And its climate was calculated, respectively, Mediterranean $(I=22 / 6)$ and semi-humid $(Q=30 / 1)$. One of the features of the Mediterranean climate is precipitation in the cold period and the sustainability of the air during the warm period of the year. However, due to the topography and elevation of the area, its precipitation is also noticeable during the warm period. The present study showed that the average annual rainfall in the area is $436.8 \mathrm{~mm}$, which is $289.34 \mathrm{~mm}$ in the cold period and $147.46 \mathrm{~mm}$ in the warm period of the year (Fig. 2). 


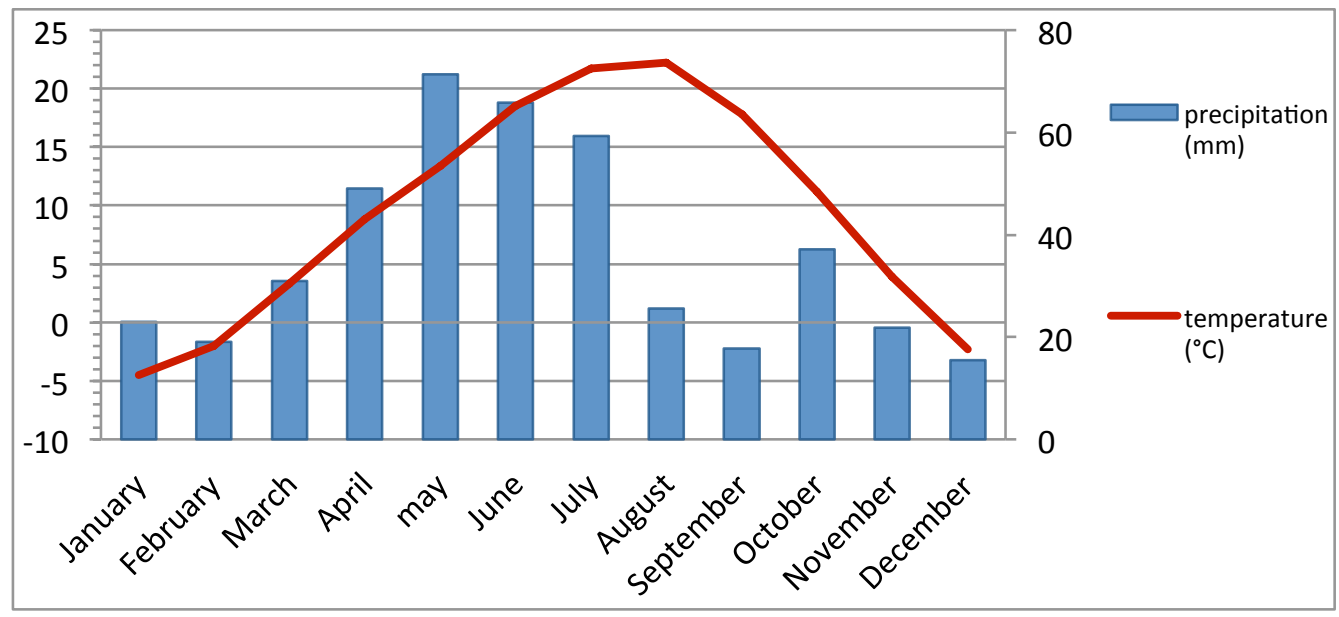

Fig 2: Climografh of chaldran

The other purpose of this study is to evaluate the climatological conditions of the Chaldran city for the development of tourism. After creating databases and statistical analysis and statistical tables, the tourism climate conditions of the studied area was evaluated using the tourism climate index (TCI) and Thermo- hygrometric index(THI).

\section{1- Tourism Climate Index (TCI)}

In this model, seven variables are used:

- Average daily temperature per month in degrees Celsius

- Daily average of relative humidity per month in percent

- Daily average of the maximum temperature per month in degrees Celsius

- Average daily minimum relative humidity per month in percent

- Daily average of total rainfall per month in millimeters

- The average daily sunny hours per month

- Average daily wind speed per month in kilometer per hour

The above variables are combined and make up 5 sub-indicators according to Table 1 . And given their impact on tourism, they earn points in the TCI model. 
Table (1): sub- indexs of the model and their impact on tourism (Mieczkowski 1985)

\begin{tabular}{|l|l|l|l|}
\hline Sub- index & Monthly climate variable & Impact on tourism & $\begin{array}{l}\text { Score in the } \\
\text { model }\end{array}$ \\
\hline $\begin{array}{l}\text { Daytime } \\
\begin{array}{l}\text { Comfort } \\
\text { (CID) }\end{array}\end{array}$ & $\begin{array}{l}\text { Average maximum daily } \\
\text { temperature }\left({ }^{\circ} \mathrm{C}\right) \text { and average } \\
\text { relative humidity }(\%)\end{array}$ & $\begin{array}{l}\text { When the tourists have the } \\
\text { maximum activity, they show a } \\
\text { warmth of comfort }\end{array}$ & 40 \\
\hline $\begin{array}{l}\text { Daily } \\
\text { Comfort } \\
\text { (CIA) }\end{array}$ & $\begin{array}{l}\text { Average } \\
\text { temperature }\left({ }^{\circ} \mathrm{C}\right) \text { and relative } \\
\text { humidity }(\%)\end{array}$ & $\begin{array}{l}\text { Indicates heat comfort throughout } \\
\text { the day and night }\end{array}$ & 10 \\
\hline $\mathrm{P}$ & $\begin{array}{l}\text { Whole precipitation }(\mathrm{mm}) \\
\mathrm{S}\end{array}$ & $\begin{array}{l}\text { Reflects the negative effect the } \\
\text { element has on holiday fun }\end{array}$ & 20 \\
\hline $\mathrm{W}$ & Averal Sunny Hours $(\mathrm{h})$ & $\begin{array}{l}\text { Its effect is positively evaluated for } \\
\text { tourism. It also has negative effect } \\
\text { when the air temperature is very } \\
\text { high }\end{array}$ & 20 \\
\hline
\end{tabular}

Finally, after obtaining the initial coefficient of each index, the coefficients are calculated in the final formula of the tourism climate index and the final coefficient and index are calculated (Mieczkowski 1985)( relation1).

$$
\mathrm{TCI}=2(4 \mathrm{CID}+\mathrm{CIA}+2 \mathrm{P}+2 \mathrm{~S}+\mathrm{W}) .
$$

After calculating the final formula, values and ranging from 0 to 100 are obtained for the indicator, which indicates the quality of the tourist climate in the region. The final result is determined from Table 5. We adjust the resulting value to the table values and finally, the quality of the tourism climate of a region is determined. As you can see in the table, the score 100 shows ideal and desirable conditions, and towards lower values, the amount of discontent and unfavorable climate conditions for tourists is increased( Table 2).

Table (2): The values and descriptive category of the TCI indicator

\begin{tabular}{|c|c|c|}
\hline Rating & Descriptive category & Indicator value \\
\hline 9 & Ideal & $90-100$ \\
\hline 8 & Excellent & $80-90$ \\
\hline 7 & Very good & $70-80$ \\
\hline 6 & Good & $60-70$ \\
\hline 5 & Acceptable & $50-60$ \\
\hline 4 & Marginal & $40-50$ \\
\hline 3 & Unfavorable & $30-40$ \\
\hline 2 & Very unfavorable & $20-30$ \\
\hline 1 & Extremely unfavorable & $10-20$ \\
\hline 0 & Impossible & $0-10$ \\
\hline
\end{tabular}




\section{2- Thermo- hygrometric index(THI)}

The index uses the air temperature (TA) and relative humidity $(\mathrm{RH})$, applicable towarm climatic conditions. It employs a simple linear equation:

$$
\mathrm{THI}=\mathrm{t}-(0.55-0.0055 \mathrm{f})(\mathrm{t}-14.5)
$$

In this relation, the THI represents the Thermo- hygrometric index, $\mathrm{t}$ is the mean dry temperature to Celsius and $\mathrm{f}$ is the average relative humidity to the percent. The temperature range and THI status are shown in Table 3.

Table(3):The categories of the thermo hygrometric index [THI; Kyle 1994 in Unger 1999]

\begin{tabular}{|c|c|}
\hline THI category & Temperature $\left({ }^{\circ} \mathrm{C}\right)$ \\
\hline Hyper-glacial & $<-40$ \\
\hline Glacial & -39.9 to -20 \\
\hline Extremely cold & -19.9 to -10 \\
\hline Very cold & -9.9 to -1.8 \\
\hline Cold & -1.7 to +12.9 \\
\hline Cool & +13 to +14.9 \\
\hline Comfortable & +15 to +19.9 \\
\hline Hot & +20 to +26.4 \\
\hline Very hot & +26.5 to +29.9 \\
\hline Torrid & $>+30$ \\
\hline
\end{tabular}

\section{Results}

\section{1- Results from the TCI model}

In the study of climate conditions affecting tourism, according to the TCI model, the tourism climate conditions of Chaldran city were analyzed on a monthly basis. And the index was obtained for each month of the year and the following results were obtained(Figure 3 and Table 4):

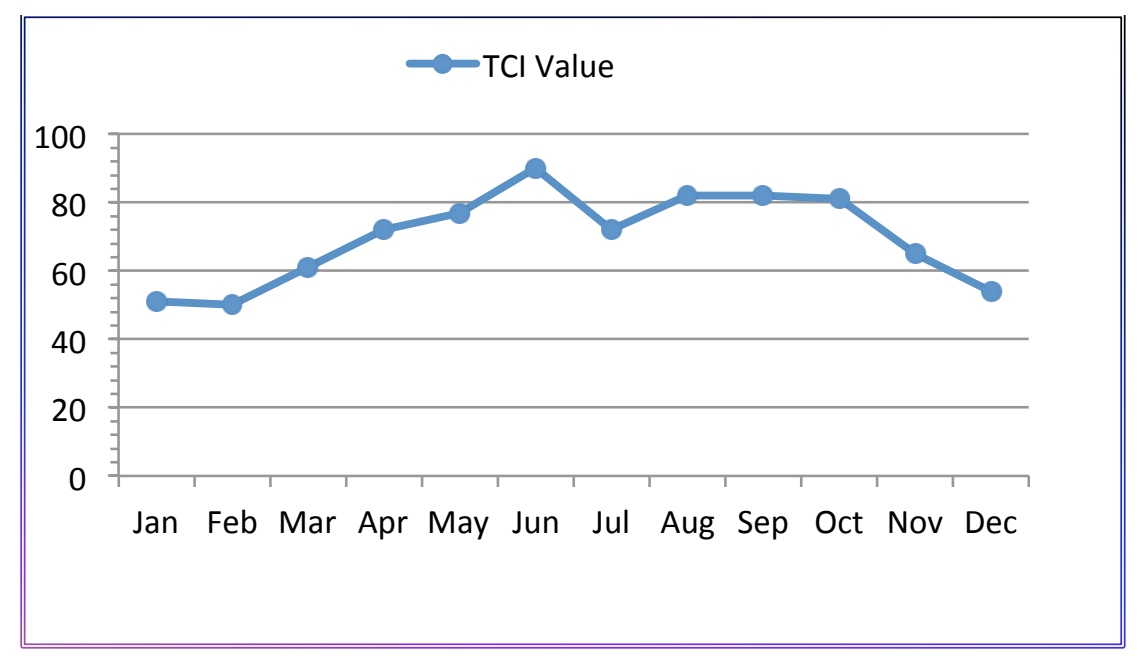

Fig3: Monthly TCI Values of Chaldran 
Mohammad Yazdani 2018, Vol.2, Issue.6, pp.11-20

Table (4): The coefficients and conditions of the tourist climate obtained for months according to the model

\begin{tabular}{|c|c|c|c|c|c|c|c|c|c|c|c|}
\hline Month & $\begin{array}{c}\text { Average } \\
\text { maximum } \\
\text { temperature } \\
\left({ }^{\circ} \mathrm{C}\right)\end{array}$ & $\begin{array}{c}\text { Average } \\
\text { relative } \\
\text { humidity } \\
(\%)\end{array}$ & $\begin{array}{c}\text { Average } \\
\text { temperatur } \\
\mathrm{e} \\
\left({ }^{\circ} \mathrm{C}\right)\end{array}$ & $\begin{array}{c}\text { Average } \\
\text { relative } \\
\text { humidity } \\
(\%)\end{array}$ & $\begin{array}{c}\text { Average } \\
\text { wind } \\
\text { speed } \\
(\mathrm{km} / \mathrm{h})\end{array}$ & $\begin{array}{c}\text { Average } \\
\text { precipitatio } \\
\mathrm{n} \\
(\mathrm{mm})\end{array}$ & $\begin{array}{c}\text { Numbe } \\
\text { r of } \\
\text { sunny } \\
\text { hours } \\
\text { per day }\end{array}$ & $\begin{array}{c}\text { CID } \\
\text { Sub- } \\
\text { index }\end{array}$ & $\begin{array}{c}\text { CIA } \\
\text { Sub- } \\
\text { index }\end{array}$ & $\begin{array}{c}\text { The final } \\
\text { coefficient } \\
\text { of the } \\
\text { tourism } \\
\text { climate }\end{array}$ & $\begin{array}{c}\text { Climate } \\
\text { conditions } \\
\text { for tourism }\end{array}$ \\
\hline Jan & 6.1 & 57.8 & -4.5 & 70.2 & 23 & 22.9 & 4.8 & 2 & 1 & 51 & Acceptable \\
\hline Feb & 8.1 & 53.1 & -2 & 66.4 & 28.5 & 19.1 & 5.5 & 2 & 1 & 50 & Acceptable \\
\hline Mar & 14.3 & 45.5 & 3.3 & 59.3 & 31.7 & 31 & 6.3 & 1.5 & 1.5 & 61 & Good \\
\hline Apr & 20.6 & 40.5 & 8.8 & 56.2 & 31.7 & 49 & 6.2 & 4 & 2 & 72 & Very good \\
\hline May & 24.4 & 41.3 & 13.4 & 57 & 26.3 & 71.44 & 7.9 & 5 & 2.5 & 77 & Very good \\
\hline Jun & 28.8 & 36.1 & 18.5 & 51.2 & 14.54 & 65.75 & 10.2 & 5 & 4 & 90 & Excellent \\
\hline Jul & 32 & 35.2 & 21.7 & 49.7 & 23.3 & 59.3 & 10.4 & 3 & 5 & 72 & Very well \\
\hline Aug & 32.2 & 30.8 & 22.2 & 45 & 24.8 & 25.6 & 10 & 3 & 5 & 82 & Excellent \\
\hline Sep & 29.34 & 34.1 & 17.8 & 48.5 & 24.1 & 17.84 & 9.3 & 4 & 3 & 82 & Excellent \\
\hline Oct & 24 & 45.1 & 11.2 & 60.7 & 26 & 37.2 & 6.9 & 5 & 2.5 & 81 & Excellent \\
\hline Nov & 14.9 & 47.9 & 3.9 & 64.6 & 25.2 & 21.76 & 5.6 & 2.5 & 1.5 & 65 & Good \\
\hline Dec & 10.3 & 53 & -2.3 & 68.2 & 25.5 & 15.5 & 5.4 & 2.5 & 1 & 54 & Acceptable \\
\hline
\end{tabular}

Weather conditions for tourism with coefficients of 50 and 51 are acceptable in January and February. The reason for the low coefficients is the existence of cooling conditions due to the dominance of the western and polar systems. Which has diminished the desirability of the climate for tourism, with the intermittent falling snow and frost. In March, the coefficient increases to 61, and the climate conditions rank well for tourism. The average temperature of this month is 7.8 degrees higher than January. And this is due to the increased energy received by the sun due to spring equinox.

In April, with the increase of the coefficient to 72, the climate of the tourist changed to a very well rating. The average temperature rises and the dominance of the western and northern systems becomes dim.

Due to the fact that the average maximum temperature of the months is May, June, July, August, September and October between 24 and $33^{\circ} \mathrm{C}$, the Trade Wind system was used to determine the initial wind speed coefficient.

The tourism climate conditions for the months of May and June amounted to 77 and 90, and were ranked very well and excellent. With a rise in temperature to 13.4 in May and 18.5 in June, the Chaldran region experiences moderate and favorable conditions.

With rising temperatures at the peak of summer, a slight decline in the desirability of climatic conditions. As of July, the final coefficient of tourism has dropped to 72 and climate conditions for tourism have been very well estimated.

Considering the mountainousness of the studied area and the effect of elevation on the decrease in temperature, the climate conditions of the tourist with a coefficient of 82 in August are in excellent condition.

With the end of summer and the onset of autumnal equilibrium, the final coefficient for the months of September and October will be 82 and 81, and will provide excellent conditions for tourists. Gradually, with the steadiness of Western systems and northern flows, the climate's desirability for tourism is reduced. So the final coefficient will be reduced to 65 in November 
and 54 in December and the climate conditions of the tourism, respectively, are well and acceptable.

\section{2- Results from the THI model}

According to Table 3 and Relationship No. 2, the values of THI and its climatic comfort were calculated for Chaldran, and Table 5 was compiled. As shown in Table 5 and Figure 4, the climatic comfort of the city was estimated to be cool for May and was favorable for the months of June, July, August, and September.

Finally, in order to overcome climatic comfort in the TCI and THI indices, the findings of both indices were compared. According to the findings of both indicators, the months of May, June, July, August and September in Chaldran were evaluated for favorable tourism.

Table(5): Bio climatic comfort Chaldran region based on Thermo-hygrometric index

\begin{tabular}{|c|c|c|c|c|}
\hline Month & $\begin{array}{c}\text { Average } \\
\text { temperature }\left({ }^{\circ} \mathrm{C}\right)\end{array}$ & $\begin{array}{c}\text { Average } \\
\text { relative humidity(\%) }\end{array}$ & THI & $\begin{array}{c}\text { THI } \\
\text { category }\end{array}$ \\
\hline Jan & -4.5 & 70.2 & 13.6 & Very cold \\
\hline Feb & -2 & 66.4 & 3 & Cold \\
\hline Mar & 3.3 & 59.3 & 5.8 & Cold \\
\hline Apr & 8.8 & 56.2 & 10.2 & Cold \\
\hline May & 13.4 & 57 & 13.7 & Cool \\
\hline Jun & 18.5 & 51.2 & 17.4 & Comfortable \\
\hline Jul & 21.7 & 49.7 & 19.7 & Comfortable \\
\hline Aug & 22.2 & 45 & 19.9 & Comfortable \\
\hline Sep & 17.8 & 48.5 & 16.9 & Comfortable \\
\hline Oct & 11.2 & 60.7 & 11.9 & Cold \\
\hline Nov & 3.9 & 64.6 & 6 & Cold \\
\hline Dec & -2.3 & 68.2 & 0.6 & Cold \\
\hline
\end{tabular}

On the other hand, according to the TCI model, Chaldran climate conditions for seven months and according to the results of the THI model, the humidity and heat conditions for four months are favorable for the comfort of tourists. In total, the comfort of climate for tourism in the Chaldran region, with a 75 percent coverage of the year, shows a special ability and special talent for tourism development.

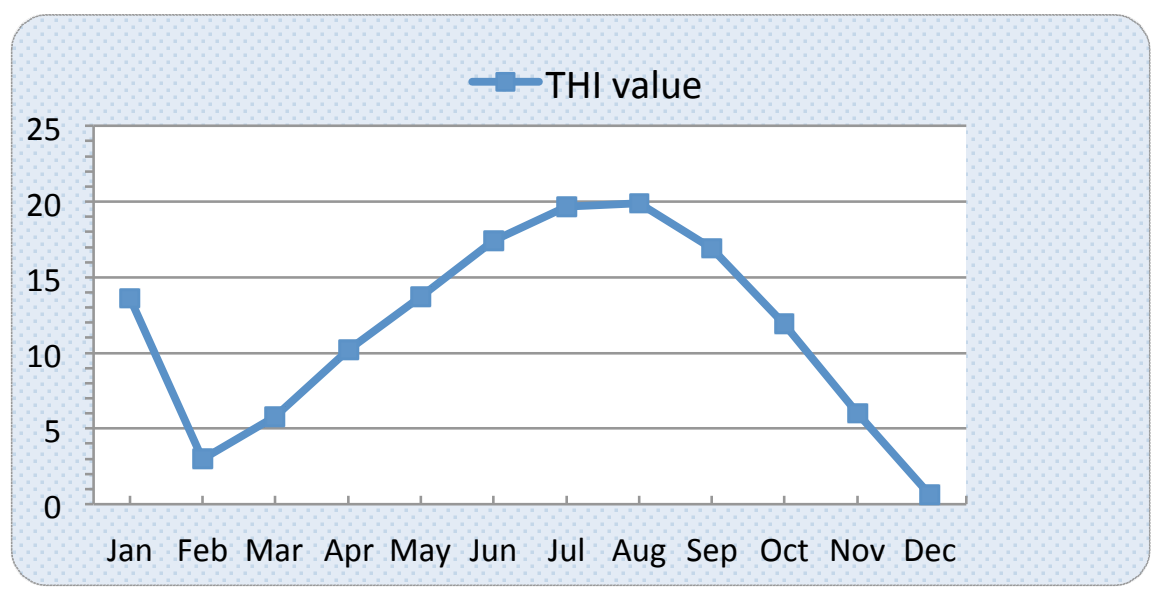

Fig4: Monthly THI Values of Chaldran 


\section{Conclusion}

The purpose of this study is to investigate the conditions of Chaldran's Bioclimatic to determine its tourist calendar. It must be said that the city is less well-known despite its natural and historical capabilities. The study showed that the bioclimatic comfort in this city could lead to the development of tourism and the economic flourishing of Chaldran.

\section{References}

Agnew, M. Palutikof, J, (2006),. Impacts of Short-term Climate Variability in the UK on Demand for Domestic and International Tourism. Climate Research, 31, 109-120.

Briedenhan, Jenny and Eugenia wickness, (2004). Tourism- Routes as a tool for the Economic Development of Rural Vibrant Hope or impossible Dream, Tourism of Management Vol. 25.

Chakavak Khajeh Amiri Khaledi.(2017). A Case Study of Evaluation and Distribution of Tourism imate by Using TCI: Baluchestan Region of Iran. Journal of Geology, 2017,1227-1237

Farajzadeh Hassan, Matzaralis Andreas, (2009), Quantification of climate for tourism in the northwest of Iran, Meteorological Applications, No. 16, 545-55.

Farzaneh Afzalinia1,Mohammad Reza Bosshaq, Soleyman Kohi;(2014). Analysis of Human Tourism Climatic Comfort using Bio-climatic indices in Dezful region, Adv. Biores., Vol 5 (3) September 2014,178-182

[6] Gomez Martin M. B., (2005), Weather, Climate and Tourism a Geography Perspective, Annals of Tourism Research. Vol. 32, NO3, 571- 591

Hartz Donna A., Brazel Anthony J., Heisler Gordon M., (2006), A case study in resort climatology of Phoenix, Arizona, USA, International Journal of Biometeorology, Vol 51, 73-83.

Hein, L. Metzger, M. J. Moreno, (2009), A Potential impacts of climate change on tourism; A Case Study for Spain. Current Opinion in Environmental Sustainability, Volume 1,170-178.

Ionac, N. (2007).Stressful bioclimatic in Dobrogea.Vol.LucrarileSeminarului Geografic “Dimitrie Cantemir",

Editura Universita_ii “Al.I. Cuza” din Iasi, 128-134.

Lin Tzu-Ping, Matzarakis Andreas, (2008), Tourism climate and thermal comfort in Sun Moon Lake,Taiwan, International Journal of Biometeorology, Vol. 52, 281-290.

Kyle, W.J. (1994). The human bioclimate of Hong Kong, Proceedings of the Contemporary Climatology Conference, pp, 345-350.

Lise W, Tol RSJ. (2002). Impact of climate on tourism demand. Climatic Change 55(4), 429-449.

Matzarakis A, (2001), Heat stress in Greece. International Journal of Biometeorology; 41:34-39.

Mieczkowski, Z., (1985), The tourism climatic index: a method of evaluating world climates for tourism. Canadian Geographer, 29(3), 220-233.

Roshan, G., Rousta, I. Ramesh, M. ,(2009),. Studying the Effects of Urban Sprawl of Metropolis on Tourism - Climate Index Oscillation: A Case Study of Tehran City. Journal of Geography and Regional Planning, 2(12), 310-321.

Toy, S. Yilmaz, S. Yilmaz H. (2007). Determination of bioclimatic comfort in three different land usesin the city of Erzurum, Turkey. Building and Environment, Vol42 (3), 1315-1318. 
World Tourist Organization, (1999); WTO Publications Unit, World Tourism Organization, Madrid, Spain.

Zengin Murat, Kopar Ibrahim, Karhan Faris, (2009), Determination of bioclimatic comfort in Erzurm-Rize expressway corridor using GIS, Building and Environment, Vol. xxx, (xx-xx), Article in Press.

Zolfaghari Hassan, (2007), Determine suitable temporal calendar for recreation in Tabriz using PET and PMV, Geographical research quarterly, No. 62, 129-141.

Zolfaghari Hassan, Moradi Farshad, (2003), The study of comfortable temperature in Kermanshah Province, Geography and regional development Journal, No. 3, 44-56. 